Prepared in cooperation with the U.S. ARMY CORPS OF ENGINEERS

\title{
Simulated Effects of Water-Level Changes in the Mississippi River and Pokegama Reservoir on Ground-Water Levels, Grand Rapids Area, Minnesota
}

Scientific Investigations Report 2005-5139 


\section{Simulated Effects of Water-Level Changes in the Mississippi River and Pokegama Reservoir on Ground-Water Levels, Grand Rapids Area, Minnesota}

By Perry M. Jones

Pepared in cooperation with the U.S. Army Corps of Engineers

Scientific Investigations Report 2005-5139 


\title{
U.S. Department of the Interior Gale A. Norton, Secretary
}

\author{
U.S. Geological Survey \\ P. Patrick Leahy, Acting Director
}

\section{U.S. Geological Survey, Reston, Virginia: 2005}

\author{
For sale by U.S. Geological Survey, Information Services \\ Box 25286, Denver Federal Center \\ Denver, CO 80225 \\ For more information about the USGS and its products: \\ Telephone: 1-888-ASK-USGS \\ World Wide Web: http://www.usgs.gov/
}

Any use of trade, product, or firm names in this publication is for descriptive purposes only and does not imply endorsement by the U.S. Government.

Although this report is in the public domain, permission must be secured from the individual copyright owners to reproduce any copyrighted materials contained within this report. 


\section{Contents}

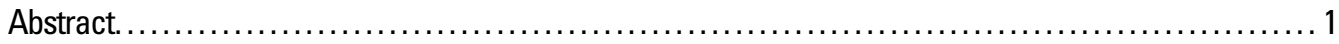

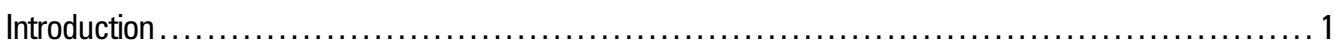

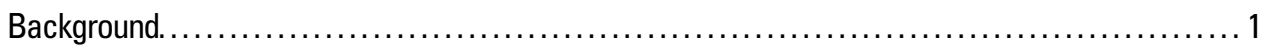

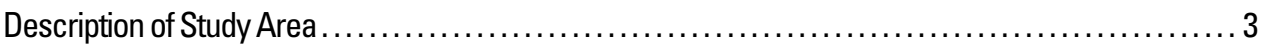

Simulated Effects of Mississippi River and Pokegama Reservoir Water-Level Changes on Ground-Water

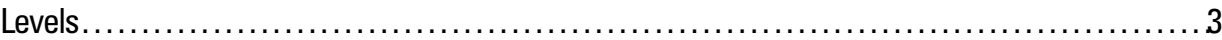

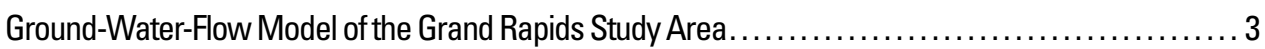

Simulation of Ground-Water Levels for Varying River and Lake Water Levels .................... 4

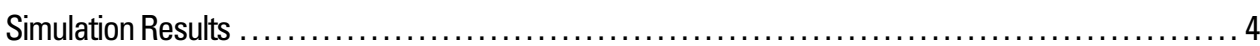

Possible Implications of Water-Level Changes in the Mississippi River and Pokegama Reservoir on

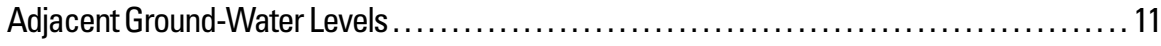

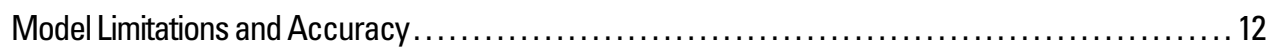

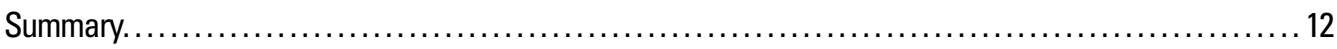

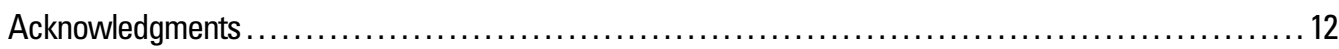

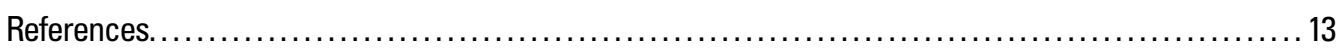

\section{Figures}

\section{1-3. Map showing:}

1. Location of modeled area, mining features, wetlands, public supply wells, streamflowgaging station, dam, hydrogeologic sections, lakes, and rivers in the Grand Rapids area, Minnesota.

2. Simulated water-level changes for middle aquifer based on a 1-foot decline and a 3-foot decline in Mississippi River and Pokegama Reservoir water levels, Grand Rapids area, Minnesota.

3. Simulated water-level changes for lower aquifer based on a 1-foot decline and a 3-foot decline in Mississippi River and Pokegama Reservoir water levels, Grand Rapids area, Minnesota .

4-7. Graph and hydrogeologic section showing:

4. Model-computed changes in water-table altitude for hypothetical water-level changes in the Mississippi River and Pokegama Reservoir compared to steady-state, calibrated values for hydrogeologic section $A-A^{\prime}$, Grand Rapids area, Minnesota. .........................

5. Model-computed changes in water-table altitude for hypothetical water-level changes in the Mississippi River and Pokegama Reservoir compared to steady-state, calibrated values for hydrogeologic section $B-B$ ', Grand Rapids area, Minnesota..........................

6. Model-computed changes in water-table altitude for hypothetical water-level changes in the Mississippi River and Pokegama Reservoir compared to steady-state, calibrated values for hydrogeologic section $C-C^{\prime}$, Grand Rapids area, Minnesota .

7. Model-computed changes in water-table altitude for hypothetical water-level changes in the Mississippi River and Pokegama Reservoir compared to steady-state, calibrated values for hydrogeologic section $D-D^{\prime}$, Grand Rapids area, Minnesota. .... 


\section{Conversion Factors and Datum}

\begin{tabular}{lll}
\hline Multiply & By & To obtain \\
\hline inch (in.) & 2.54 & centimeter $(\mathrm{cm})$ \\
foot $(\mathrm{ft})$ & 0.3048 & meter $(\mathrm{m})$ \\
mile $(\mathrm{mi})$ & 1.609 & kilometer $(\mathrm{km})$ \\
square mile $\left(\mathrm{mi}^{2}\right)$ & 2.590 & square kilometer $\left(\mathrm{km}^{2}\right)$ \\
\hline
\end{tabular}

Temperature in degrees Celsius $\left({ }^{\circ} \mathrm{C}\right)$ may be converted to degrees Fahrenheit $\left({ }^{\circ} \mathrm{F}\right)$ as follows:

${ }^{\circ} \mathrm{F}=\left(1.8 \mathrm{x}^{\circ} \mathrm{C}\right)+32$.

Temperature in degrees Fahrenheit $\left({ }^{\circ} \mathrm{F}\right)$ may be converted to degrees Celsius $\left({ }^{\circ} \mathrm{C}\right)$ as follows:

${ }^{\circ} \mathrm{C}=\left({ }^{\circ} \mathrm{F}-32\right) / 1.8$.

Vertical coordinate information is referenced to the North American Vertical Datum of 1988 (NAVD 88).

Horizontal coordinate information is referenced to the North American Datum of 1983 (NAD 83).

Altitude, as used in this report, refers to distance above the vertical datum.

Water year: The water year is the 12-month period October 1 through September 30 and is named for the calendar year in which it ends. 


\title{
Simulated Effects of Water-Level Changes in the Mississippi River and Pokegama Reservoir on Ground- Water Levels, Grand Rapidss Area, Minnesota
}

\author{
By Perry M. Jones
}

\section{Abstract}

The U.S. Geological Survey, in cooperation with the U.S. Army Corps of Engineers, used an existing, three-dimensional, numerical ground-water flow model (referred to as the calibrated model) to assess the effects of water-level changes in the Mississippi River and Pokegama Reservoir on ground-water levels in adjacent glaciofluvial aquifers in the Grand Rapids area of north-central Minnesota. Pokegama Reservoir consists of Pokegama Lake, Little Jay Gould Lake, Jay Gould Lake, Cut-off Lake, and Blackwater Lake. Water levels in the Pokegama Reservoir are regulated at Pokegama Dam on the Mississippi River west of Grand Rapids. A steady-state model was used, and simulations represent "worse-case" scenarios for the effects of lowering or raising the river and lake water levels. The simulated ground-water levels represent levels that would result if the river and lake stages permanently declined or rose by the specified amounts. Eight hypothetical scenarios were simulated by varying water levels in the Mississippi River and Pokegama Reservoir from values used in the calibrated model. In the simulations, water levels for the Mississippi River, riverine wetlands of the Mississippi River, and lakes of the Pokegama Reservoir were raised and lowered uniformly by $0.50,1.00,2.00$, and 3.00 feet from calibrated water levels.

The extent of aquifer water-level changes resulting from these river, wetland, and lake water-level changes varied because of the complex hydrogeology of the study area. A 1.00 -foot decline in reservoir/river water levels caused a maximum simulated ground-water-level decline in the middle aquifer near Jay Gould and Little Jay Gould Lakes of 1.09 feet and a maximum simulated ground-water-level decline of 1.00 foot in the lower aquifer near Cut-off and Blackwater Lakes. The amount and extent of ground-water-level changes in the middle and lower aquifers can be explained by the thickness, extent, and connectivity of the aquifers. Surface-water/ground-water interactions near wetlands and lakes with water levels unchanged from the calibrated model resulted in small watertable altitude differences among the simulations. Results of the ground-water modeling indicate that lowering of the reservoir and river water levels by 1.00 foot likely will not substantially affect water levels in the middle and lower aquifers.

\section{Introduction}

\section{Background}

The effects of reservoir water-level management on the environment, public water supplies, and recreation are a concern in the Mississippi River headwater reservoirs of northcentral Minnesota (fig. 1). The Mississippi River headwaters reservoirs consist of six primary lakes (Leech Lake, Lake Winnibigoshish, Pokegama Lake, Big Sandy Lake, Cross Lake (Pine River Dam), and Gull Lake) (U.S. Army Corp of Engineers, 2003a). Dams for these reservoirs were constructed between 1884 and 1912. These reservoirs were initially created to augment flow in the Mississippi River for navigation but are currently (2005) used to maintain water levels to meet recreational, flood-control, and shoreline erosion reduction needs.

Water-level management in the six Mississippi River headwater reservoirs is focused on controlling summer water levels for recreational purposes and lowering water levels in the winter. An attempt is made each summer in each of the six reservoirs to hold water levels within a set range, which varies from 0.25 to $0.50 \mathrm{ft}$ for each of the reservoirs. Water levels exceed these ranges following large summer storms or during drought conditions. Minimum flows for each of the reservoirs are established by the U.S. Army Corps of Engineers (USACE) and the Minnesota Department of Natural Resources (MDNR) to provide sufficient water for downstream aquatic life during dry periods. In the fall and winter months, water levels are lowered to provide adequate storage capacity for the spring snowmelt.

USACE is conducting a long-range planning study, termed the Reservoir Operating Plan Evaluation (ROPE), to evaluate alternative plans to improve operations of the Mississippi River headwater reservoirs (U.S. Army Corps of Engineers, 2003a). As part of the ROPE study, USACE is investigating the effects 


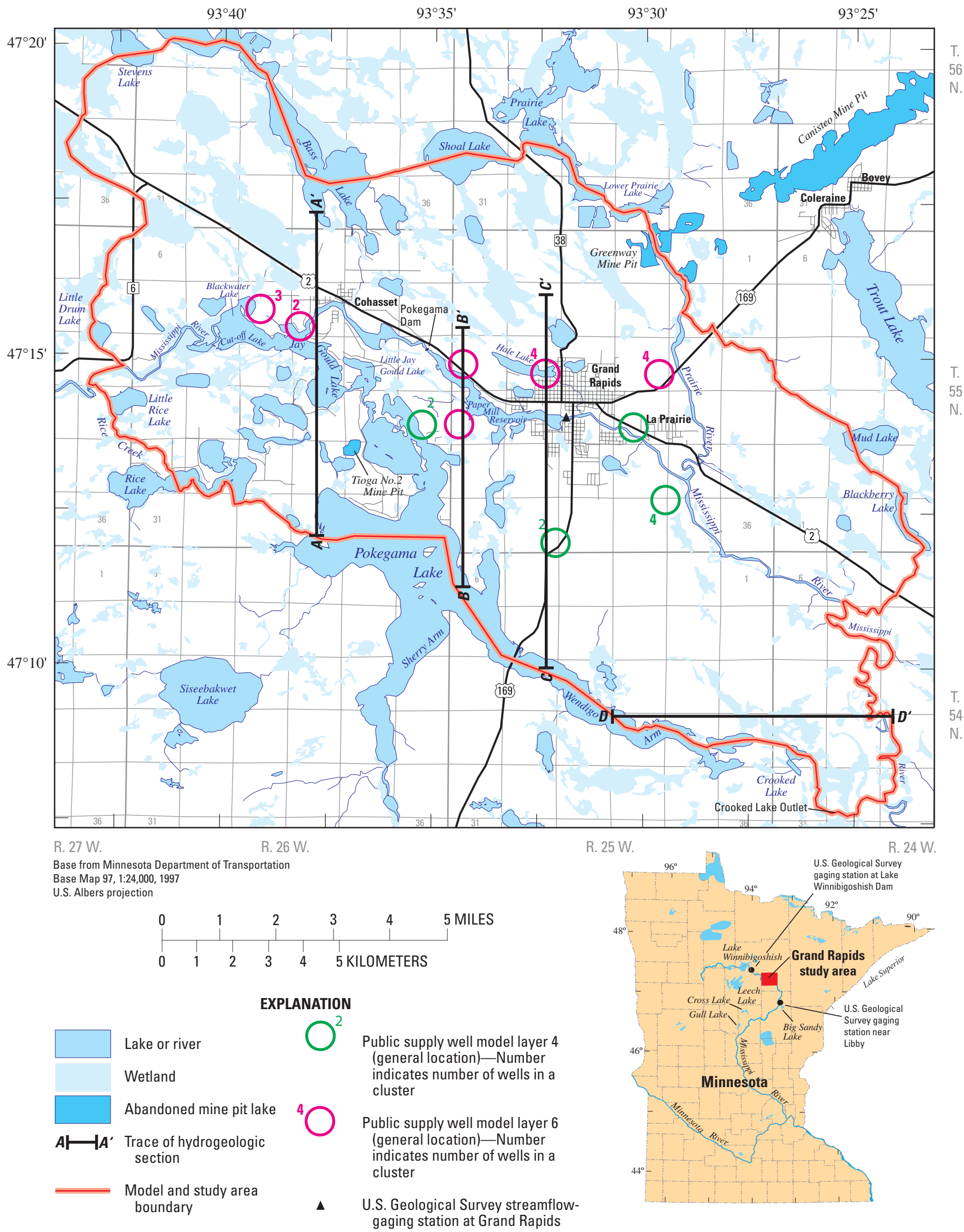

Figure 1. Location of modeled area, mining features, wetlands, public supply wells, streamflow-gaging station, dam, hydrogeologic sections, lakes, and rivers in the Grand Rapids area, Minnesota. 
of lowering reservoir water levels in northern Minnesota to produce more natural flow conditions during the summer and fall for downstream river reaches. With the establishment of the reservoirs, extensive areas of river flood plain have become permanently inundated, affecting shallow aquatic and wetland habitats (U.S. Army Corps of Engineers, 2003b). USACE is currently (2005) planning a maximum water-level change of $\pm 1.00 \mathrm{ft}$ (Edward McNally, U.S. Army Corps of Engineers, oral commun., November 1, 2004).

USACE is concerned that lowering water levels in the Mississippi River headwater reservoirs may have detrimental effects on local and downstream ground-water supplies. Surficial and confined glacial aquifers downstream of the reservoirs are used for residential and public water supplies. Some of these aquifers are hydraulically connected to the Mississippi River and the reservoirs (Oakes, 1970). Therefore, changes in river and reservoir water levels may adversely affect water levels and yields to wells in the aquifers.

The U.S. Geological Survey (USGS), in cooperation with USACE, used an existing steady-state, ground-water flow model (Jones, 2004) to assess the effects of water-level changes in the Mississippi River and Pokegama Reservoir on groundwater levels in adjacent glaciofluvial aquifers. Pokegama Reservoir consists of Pokegama Lake, Little Jay Gould Lake, Jay Gould Lake, Cut-off Lake, and Blackwater Lake (fig. 1). Water levels in Pokegama Reservoir are regulated at Pokegama Dam, which is located on the Mississippi River approximately $1.3 \mathrm{mi}$ southeast of the city of Cohasset (fig. 1). USACE hydrologists will use results from the model simulations to make preliminary decisions regarding maintenance of water levels in the six headwaters reservoirs.

This report presents the results from the simulated steadystate response of ground-water levels in glaciofluvial aquifers in the Grand Rapids area to changes in water levels in the Mississippi River and Pokegama Reservoir. The report compares the results of eight hypothetical scenarios in which water levels in the Mississippi River and Pokegama Reservoir were raised and lowered by $0.50,1.00,2.00$, and $3.00 \mathrm{ft}$ from the levels used in the model, which represented long-term average, steady-state conditions. This report provides a comparison of ground-water levels from the hypothetical simulations and the steady-state model using maps and hydrogeologic sections. A detailed description of the physical setting and hydrogeology of the Grand Rapids area, as well as information on the construction, calibration, and sensitivity of the ground-water flow model, can be found in Jones (2004).

\section{Description of Study Area}

The study area encompasses an area of about $114 \mathrm{mi}^{2}$ surrounding the city of Grand Rapids (population 7,764 in 2000; U.S. Census Bureau, 2002) in Itasca County, north-central Minnesota (fig. 1). Land-surface altitudes range from $1,240 \mathrm{ft}$ along the Mississippi River in the southeast part of the study area to $1,480 \mathrm{ft}$ east of Pokegama Lake and south of Grand Rapids. The mean annual temperature (1961-90) at Grand Rapids is $38.6^{\circ} \mathrm{F}$, and the mean annual precipitation is $27.54 \mathrm{in}$. (Minnesota State Climatologist, 2001). Glaciofluvial and bedrock aquifers are the main sources of ground-water withdrawal in the area. Withdrawals are primarily through municipal, small industrial, and domestic wells. The glaciofluvial aquifers are composed of glaciofluvial sediment that is separated or overlain by glacial tills or discontinuous deposits of glaciofluvial sediment. The primary bedrock aquifer in the study area is the Biwabik Iron Formation, which is composed of chert, shale, and iron minerals (Morey, 1972).

\section{Simulated Effects of Mississippi River and Pokegama Reservoir Water-Level Changes on Ground-Water Levels}

An existing three-dimensional, numerical ground-water flow model of the Grand Rapids area was used to perform a series of simulations to assess the effect of changes in Mississippi River and Pokegama Reservoir water levels on ground-water resources (Jones, 2004). The USGS MODular ground-water-FLOW model, MODFLOW, version 1996, was used to develop the steady-state model. MODFLOW is a modular, finite-difference model that simulates ground-water flow in multiple aquifers (Harbaugh and McDonald, 1996). This steady-state model was calibrated using estimated base flows in reaches of the Mississippi and Prairie Rivers from Payne (1995) and water levels measured in wells between 1975 and 1999 (Jones, 2004).

\section{Ground-Water-Flow Model of the Grand Rapids Study Area}

The calibrated ground-water flow model of the Grand Rapids study area consisted of six layers, representing glaciofluvial sediment (sand, gravel, and boulder deposited by glacial meltwaters) separated by layers of glacial clay and till (a mixture of clay, sand, gravel, and boulders) (Jones, 2004). Groundwater flow in bedrock aquifers below the glacial material was not incorporated into the model. Ground water was withdrawn from three glaciofluvial units, defined as the upper, middle, and lower aquifers.

All lakes and perennial wetlands were represented in the calibrated model as general-head boundaries. Streams and rivers not simulated as part of wetlands were simulated using the River package in MODFLOW. Withdrawals from the 24 public supply wells in the study area (fig. 1) were simulated with the Well Package in MODFLOW. A specified-flux boundary was used to represent areal recharge to the surficial layer of the model using the Recharge Package in MODFLOW. The MODFLOW simulations were executed and analyzed using the Groundwater Modeling System (GMS) (U.S. Department of 


\section{Simulated Effects of Water-Level Changes in the Mississippi River and Pokegama Reservoir on Ground-Water Levels}

Defense, 1998). A full description of the model calibration and sensitivity analyses can be found in Jones (2004).

Water-level altitude data for the perennial wetlands, rivers, and lakes used in the model were obtained from the National Wetlands Inventory database (U.S. Fish \& Wildlife Service, 1994) and from the MDNR Lake Level database (Minnesota Department of Natural Resources, 2002). A water level of $1,272.96 \mathrm{ft}$ was used in general-head boundaries representing Pokegama Reservoir in the calibrated model. The mean daily water level for Pokegama Lake, within the reservoir, between 1990 and 2003 was $1,272.65 \mathrm{ft}$. Water levels in the calibrated model for the Mississippi River ranged from $1,243.93 \mathrm{ft}$ in the southeastern part of the model area to $1,275.10 \mathrm{ft}$ in the western part.

\section{Simulation of Ground-Water Levels For Varying River and Lake Water Levels}

Eight simulations were executed on the basis of varying river and lake water levels from values used in the calibrated model for the Mississippi River and Pokegama Reservoir. In the simulations, water levels for river segments used to represent the Mississippi River, general-head segments used to represent the riverine wetlands of the Mississippi River, and general-head segments used to represent the lakes for Pokegama Reservoir were raised and lowered uniformly by $0.50,1.00,2.00$, and $3.00 \mathrm{ft}$ from the calibrated model levels. The simulated reach of the Mississippi River was from Rice Creek outlet in the west to Crooked Lake outlet in the southeast (fig. 1). USACE currently (2005) does not have plans to lower or raise the water level in the Mississippi River downgradient from Pokegama Dam (fig. 1). In the hypothetical simulations, however, water levels downgradient from Pokegama Dam were raised and lowered to assess the effects of water-level changes in the Mississippi River under various hydrogeologic conditions.

Differences in ground-water levels between the hypothetical simulations and the calibrated model were calculated for each layer of the model. Differences in the two most widely used aquifers in the area, the middle and lower aquifers, were evaluated to assess the effect that river and reservoir water levels may have on local ground-water levels. Model-computed differences in water-table altitudes between the hypothetical simulations and the calibrated model were determined along four hydrogeologic sections in the study area (fig. 1). These hydrogeologic sections represent a range of hydrogeologic settings present in the study area. The locations of those sections were chosen in areas where the number of dry model cells was low.

\section{Simulation Results}

Simulated ground-water levels were affected primarily in areas nearest to the Mississippi River and Pokegama Reservoir where the hypothetical surface-water-level changes were made. The effects of these changes decreased with greater distances from the river and reservoir. Simulated ground-water levels did not change much in areas where water levels in surface-water bodies were not changed.

The extent of aquifer water-level changes resulting from the lowering or raising of water levels in the Mississippi River and Pokegama Reservoir varied in the study area. This variability is due mainly to the complex hydrogeology of the area as exhibited by substantial variability in the thicknesses and extents of the upper, middle, and lower aquifers (figs. 2-7). The amount of ground-water-level change is controlled mainly by: (1) surface-water/ground-water interactions near wetlands and lakes with water levels unchanged from the calibrated model; (2) the relative location of a given point in the aquifers in relation to the Mississippi River and Pokegama Reservoir; and (3) the thickness, extent, hydraulic conductivity, and connectivity of the aquifers to surface-water bodies.

Surface-water/ground-water interactions near wetlands and lakes in which the surface-water levels were not changed in the simulations (for example, Bass Lake, in hydrogeologic section $A-A^{\prime}$; wetlands in the center of hydrogeologic section $D-$ $D^{\prime}$; figs. 1 and 7) resulted in small hypothetical changes in ground-water levels. The amount of water-table change was small near wetlands and lakes between Pokegama Lake and Jay Gould Lake in hydrogeologic section $A-A^{\prime}$ (figs. 1 and 4) and west of the Mississippi River in hydrogeologic section $D-D^{\prime}$ (fig. 7). Small water-table changes also were seen adjacent to wetlands and lakes near Pokegama Lake in hydrogeologic section $D-D^{\prime}$ (fig. 7) where water-table changes near the lake were only $2.00 \mathrm{ft}$ with a $3.00-\mathrm{ft}$ water-level change as a result of local wetlands and lakes.

The maximum ground-water-level decline in the middle aquifer was $3.05 \mathrm{ft}$ for the $3.00-\mathrm{ft}$ decline in reservoir/river water levels, which occurred in areas around Jay Gould and Little Jay Gould Lakes and Paper Mill Reservoir, and in several areas of Pokegama Lake (figs. 1 and 2). The maximum groundwater-level decline in the lower aquifer was $2.90 \mathrm{ft}$ for the 3.00-ft decline in reservoir/river water levels, which also occurred in the Jay Gould and Little Jay Gould Lake area (fig. 3). In both the middle and lower aquifers, the amount and areal extent of these changes were greater for the $3.00-\mathrm{ft}$ decline than for the $1.00-\mathrm{ft}$ decline. The maximum ground-water-level decline in the middle and lower aquifers for the 1.00-ft decline in reservoir/river water levels was 1.09 and $1.00 \mathrm{ft}$, respectively (figs. 2 and 3).

Simulated ground-water levels declined slightly and even rose in the middle and lower aquifers in the Grand Rapids area and to the east and southeast of Grand Rapids (figs. 1 and 2). The maximum ground-water-level rises were 1.09 and $0.19 \mathrm{ft}$ in the middle and lower aquifers, respectively, for the $1.00-\mathrm{ft}$ decline in reservoir/river water levels (figs. 2 and 3). For the $3.00-\mathrm{ft}$ decline in reservoir/river water levels, the maximum ground-water-level rises were 3.10 and $0.98 \mathrm{ft}$ in the middle and lower aquifers, respectively. Because model cells in the upper two model layers became dewatered as a result of the simulated lowering of water levels in the Mississippi River for all eight 


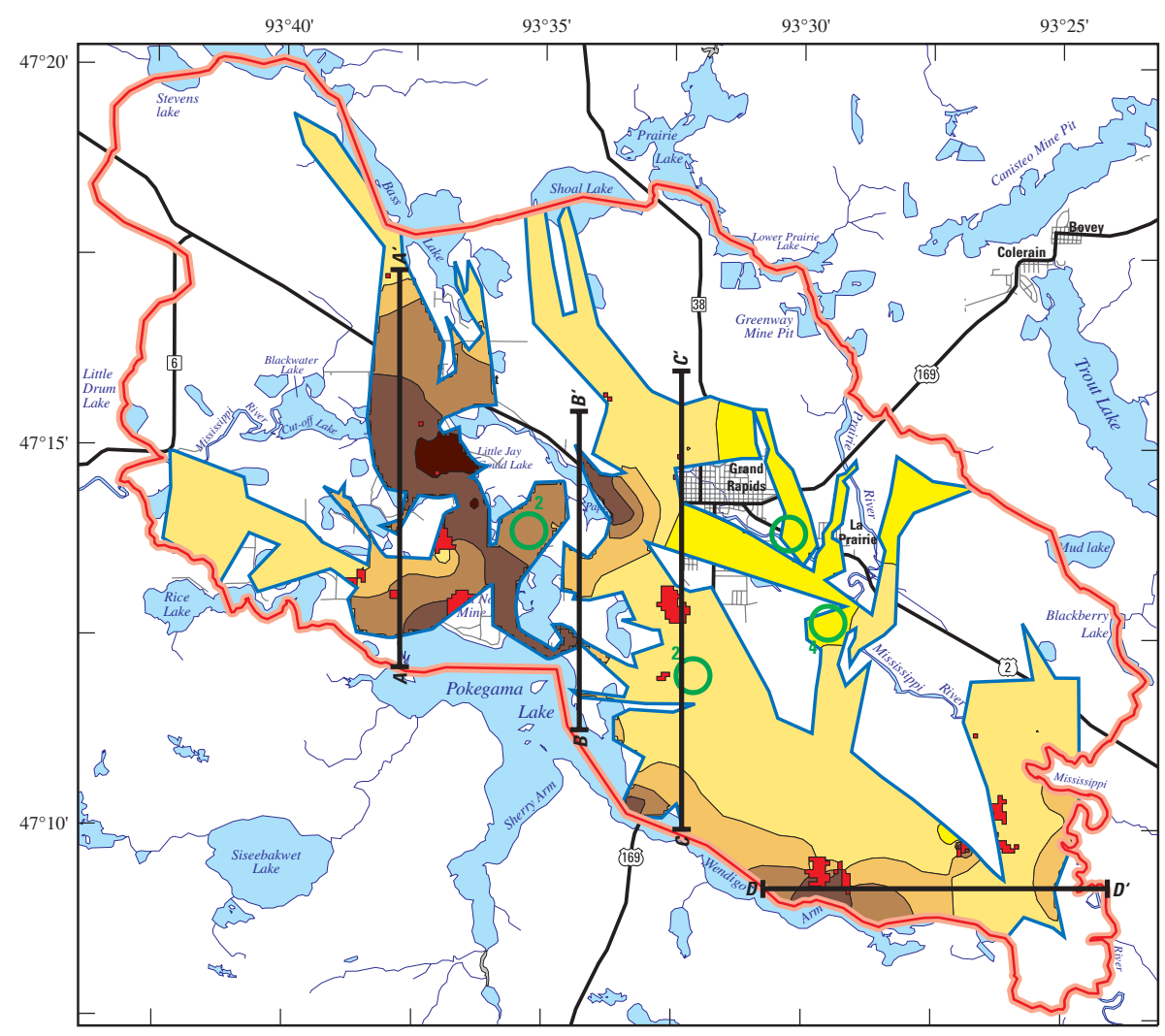

(a) Simulated ground-waterlevel changes resulting from 1foot decline in reservoir/river water levels

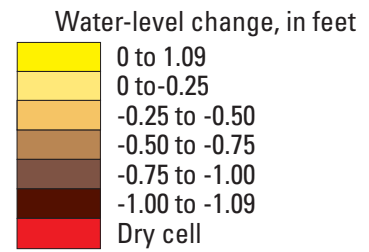

\section{(b) Simulated ground-water- level changes resulting from 3- foot decline in reservoir/river water levels}

\begin{tabular}{|l|}
\hline Water-level change, in feet \\
\hline \\
0 to 3.10 \\
0 to- 0.25 \\
-0.25 to -0.50 \\
-0.50 to -0.75 \\
-0.75 to -1.00 \\
-1.00 to -1.25 \\
-1.25 to -1.50 \\
-1.50 to -1.75 \\
-1.75 to -2.00 \\
-2.00 to -2.25 \\
-2.25 to -2.50 \\
-2.50 to -2.75 \\
-2.75 to -3.00 \\
-3.00 to -3.05 \\
Dry cell \\
\hline \\
\hline \\
\hline EXPLANATION
\end{tabular}

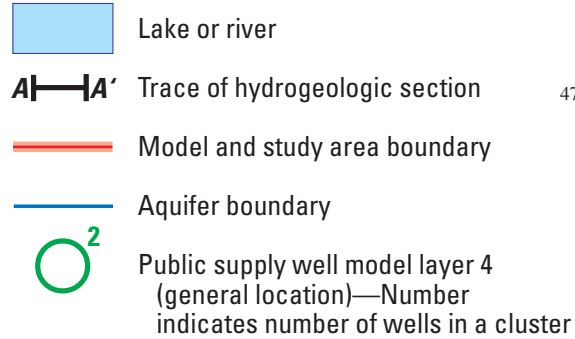

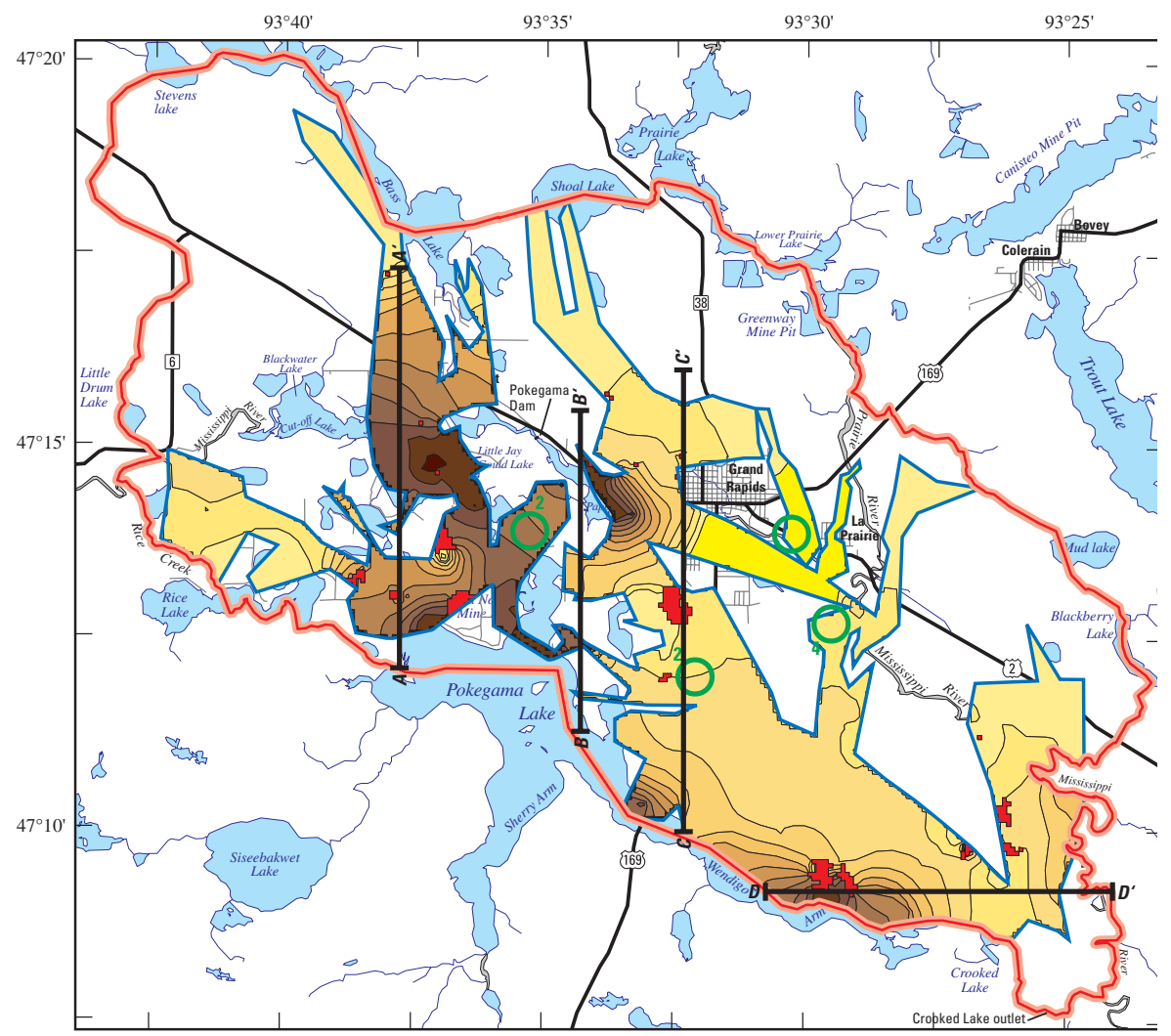

Figure 2. Simulated water-level changes for middle aquifer (model layer 4) based on (a) a 1-foot decline and (b) a 3-foot decline in Mississippi River and Pokegama Reservoir water levels, Grand Rapids area, Minnesota. 


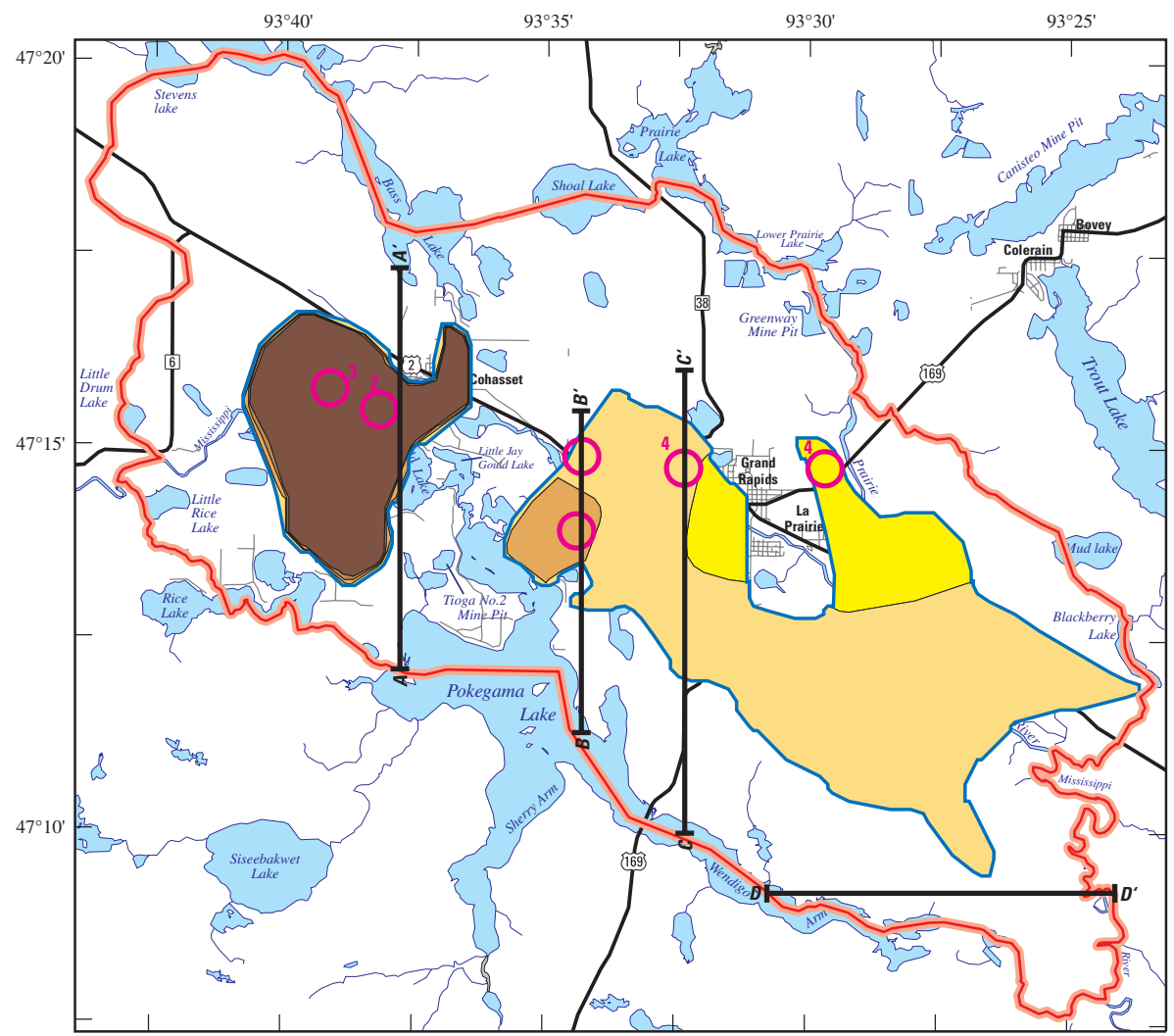

(a) Simulated ground-waterlevel changes resulting from 1foot decline in reservoir/river water levels

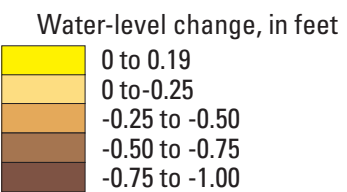

(b) Simulated ground-waterlevel changes resulting from 3foot decline in reservoir/river water levels

\begin{tabular}{|l} 
Water-level change, in feet \\
\hline \\
0 to 0.98 \\
0 to -0.25 \\
-0.25 to -0.50 \\
-0.50 to -0.75 \\
-0.75 to -1.00 \\
-1.00 to -1.25 \\
-1.25 to -1.50 \\
-1.50 to -1.75 (not visable) \\
-1.75 to -2.00 (not visable) \\
-2.00 to -2.25 \\
-2.25 to -2.50 \\
-2.50 to -2.75 \\
-2.75 to -2.90 (not visable)
\end{tabular}

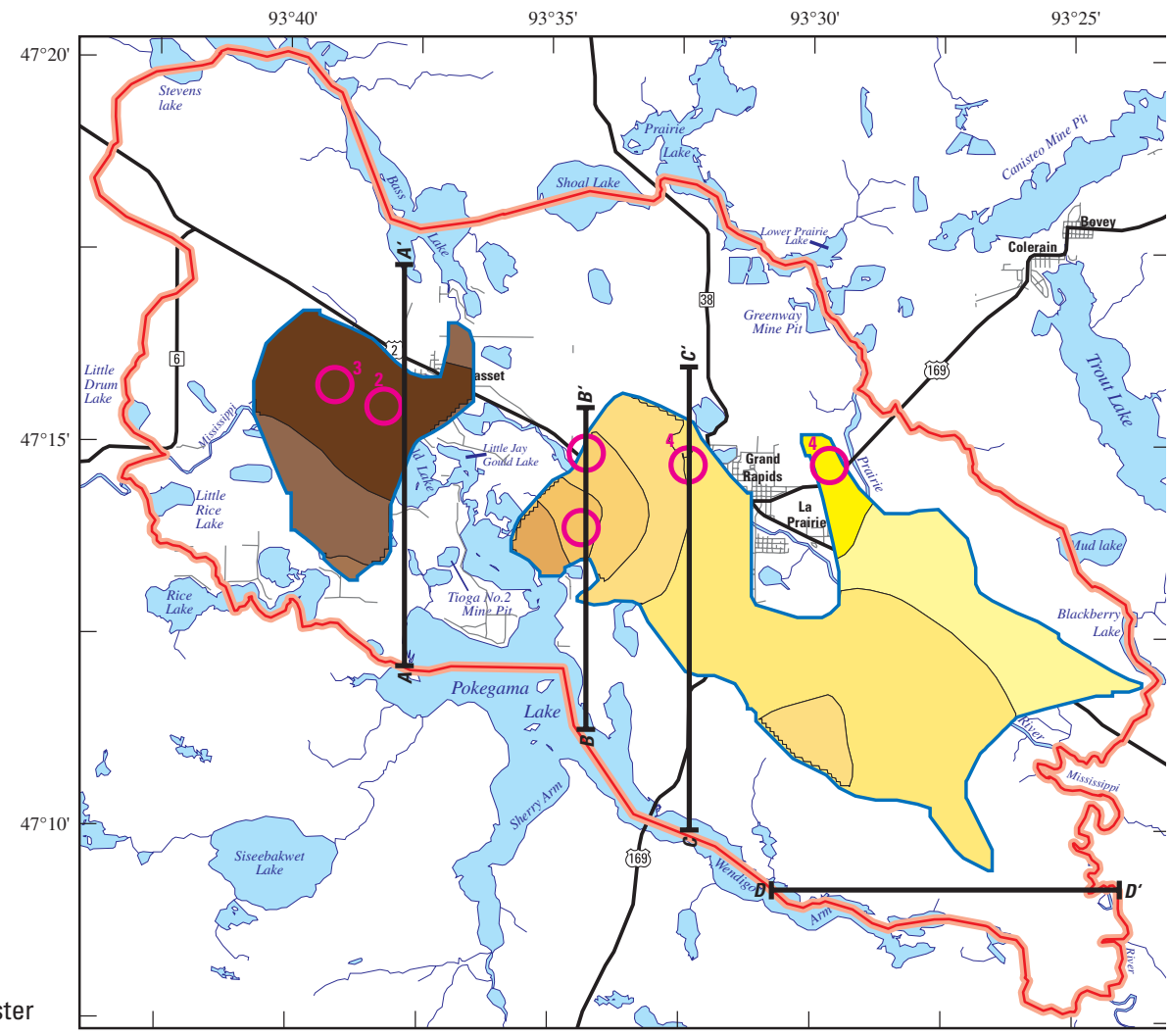

Figure 3. Simulated water-level changes for lower aquifer (model layer 6) based on (a) a 1-foot decline and (b) a 3-foot decline in Mississippi River at Pokegama Reservoir water levels, Grand Rapids area, Minnesota. 


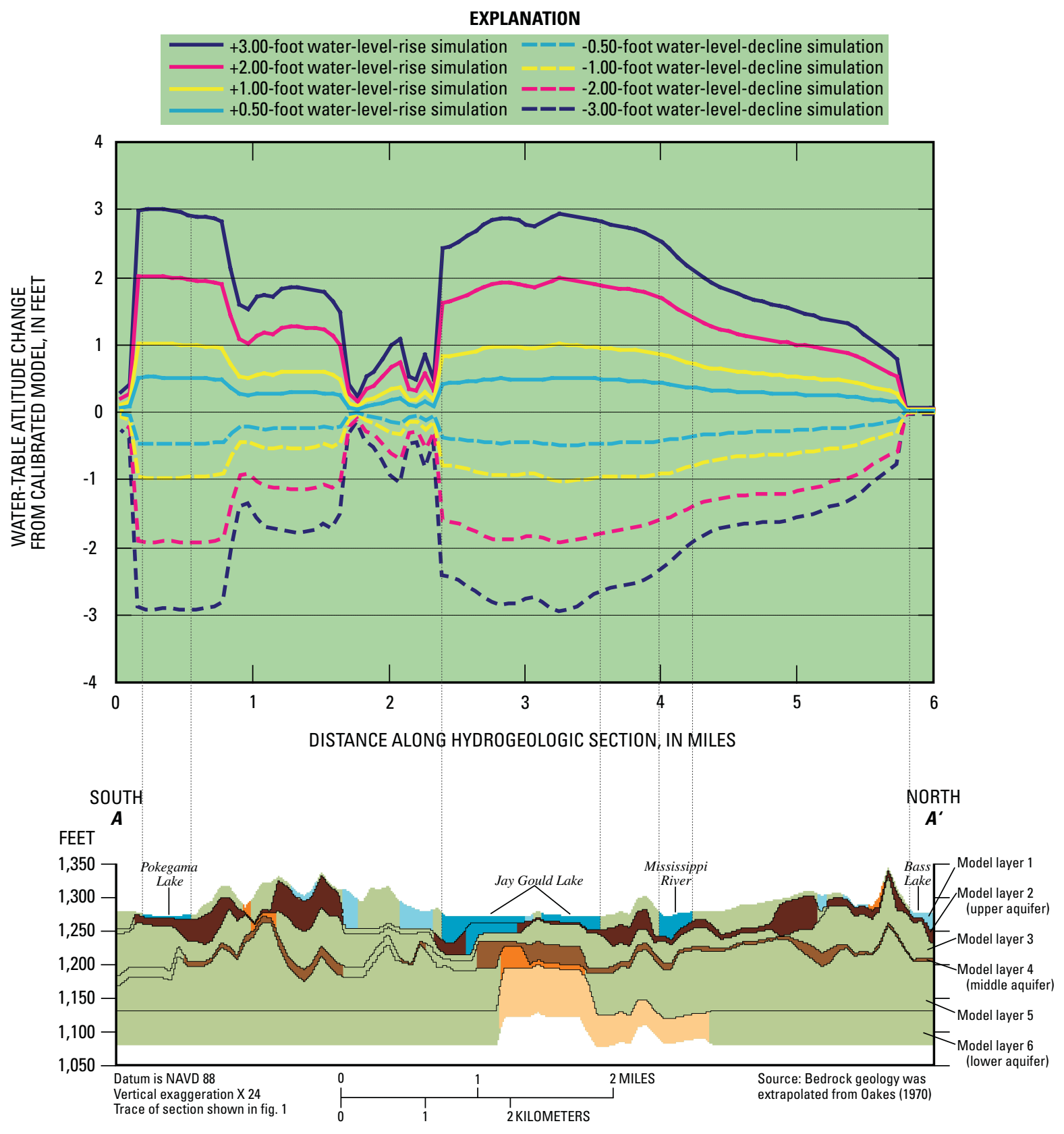

EXPLANATION

Hydrogeologic units

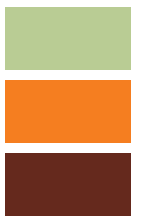

Glacial till
Glaciofluvial sediment separating aquifers

Upper aquifer-Hydraulic conductivity of 220 feet per day
Middle aquifer-Hydraulic conductivity of 98 feet per day

Lower aquifer-Hydraulic conductivity of 98 feet per day

River, reservoir, or lake-Stage adjusted in the model

River, lake, or wetland-Stage unadjusted in the model

Figure 4. Model-computed changes in water-table altitude for hypothetical water-level changes in the Mississippi River and Pokegama Reservoir compared to steady-state, calibrated values for hydrogeologic section $A-A^{\prime}$, Grand Rapids area, Minnesota. 


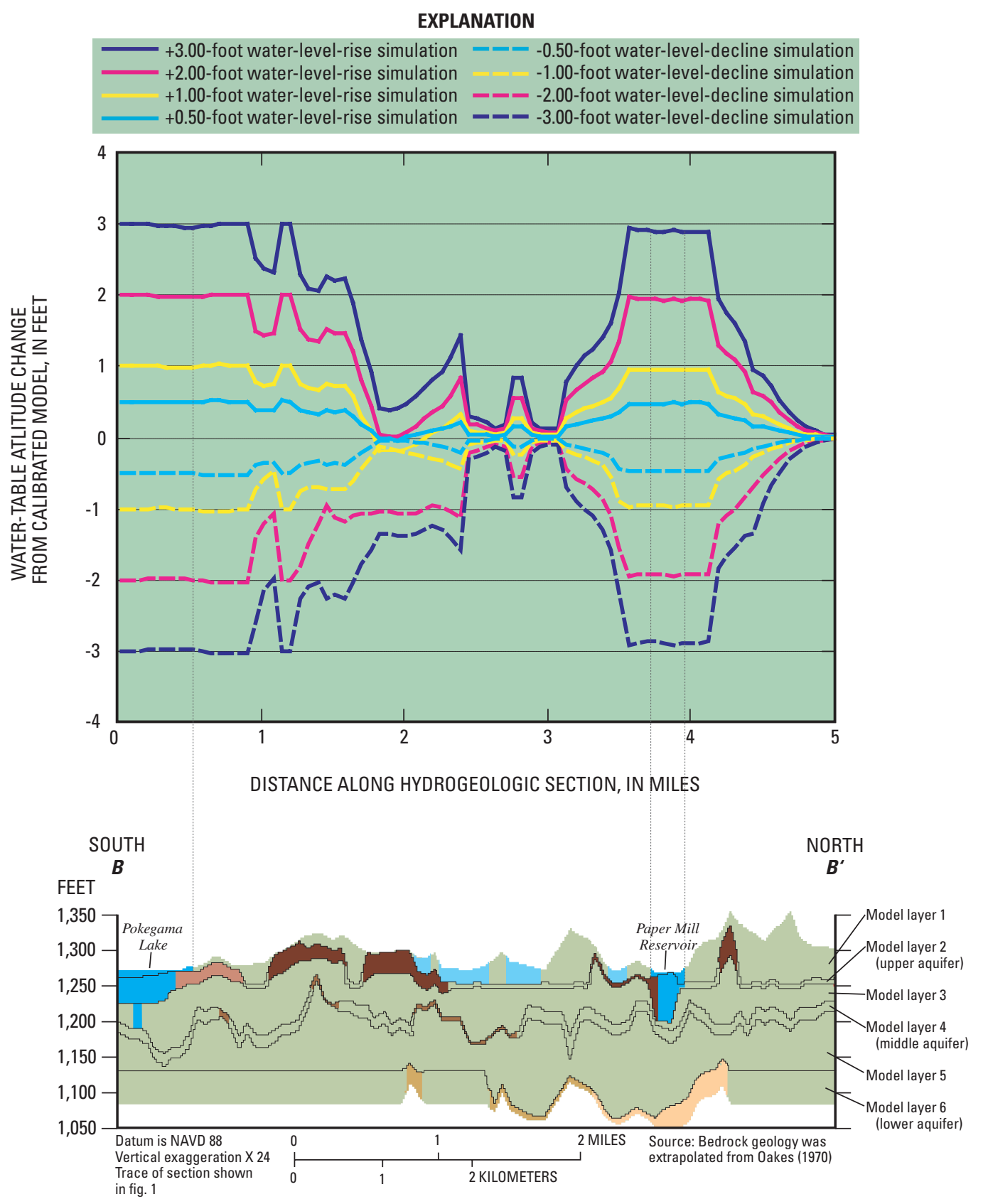

EXPLANATION

Hydrogeologic units

Glacial till

Upper aquifer-Hydraulic conductivity of 220 feet per day

Upper aquifer-Hydraulic conductivity of 98 feet per day

Middle aquifer-Hydraulic conductivity of 98 feet per day
Lower aquifer-Hydraulic conductivity of 110 feet per day

Lower aquifer-Hydraulic conductivity of 270 feet per day

River, reservoir, or lakes-Stage adjusted in the model

River, lake, or wetland-Stage unadjusted in the model

Figure 5. Model-computed changes in water-table altitude for hypothetical water-level changes in the Mississippi River and Pokegama Reservoir compared to steady-state, calibrated values for hydrogeologic section $B-B^{\prime}$, Grand Rapids area, Minnesota. 


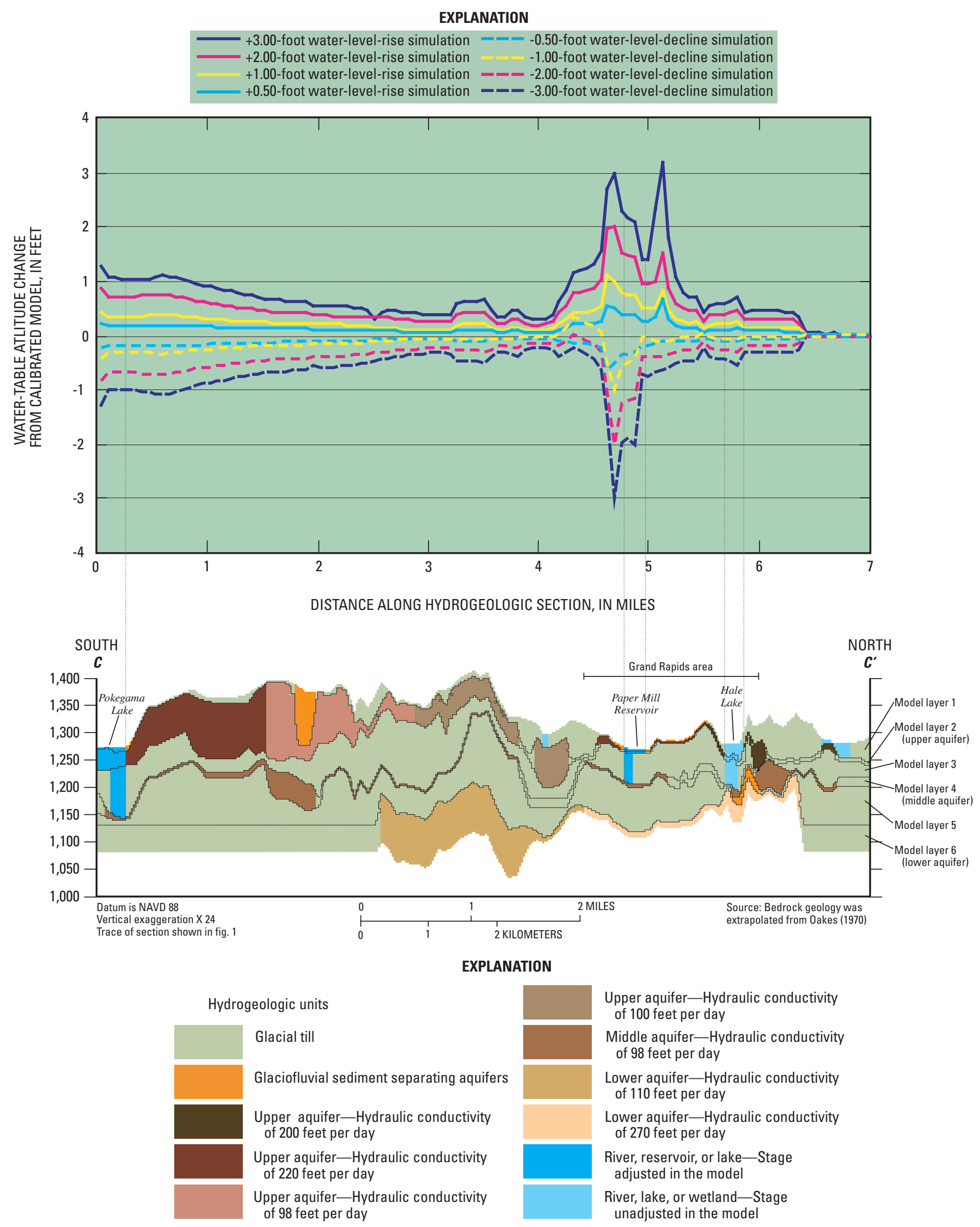

Figure 6. Model-computed changes in water-table altitude for hypothetical water-level changes in the Mississippi River and Pokegama Reservoir compared to steady-state, calibrated values for hydrogeologic section $C-C^{\prime}$, Grand Rapids area, Minnesota. 


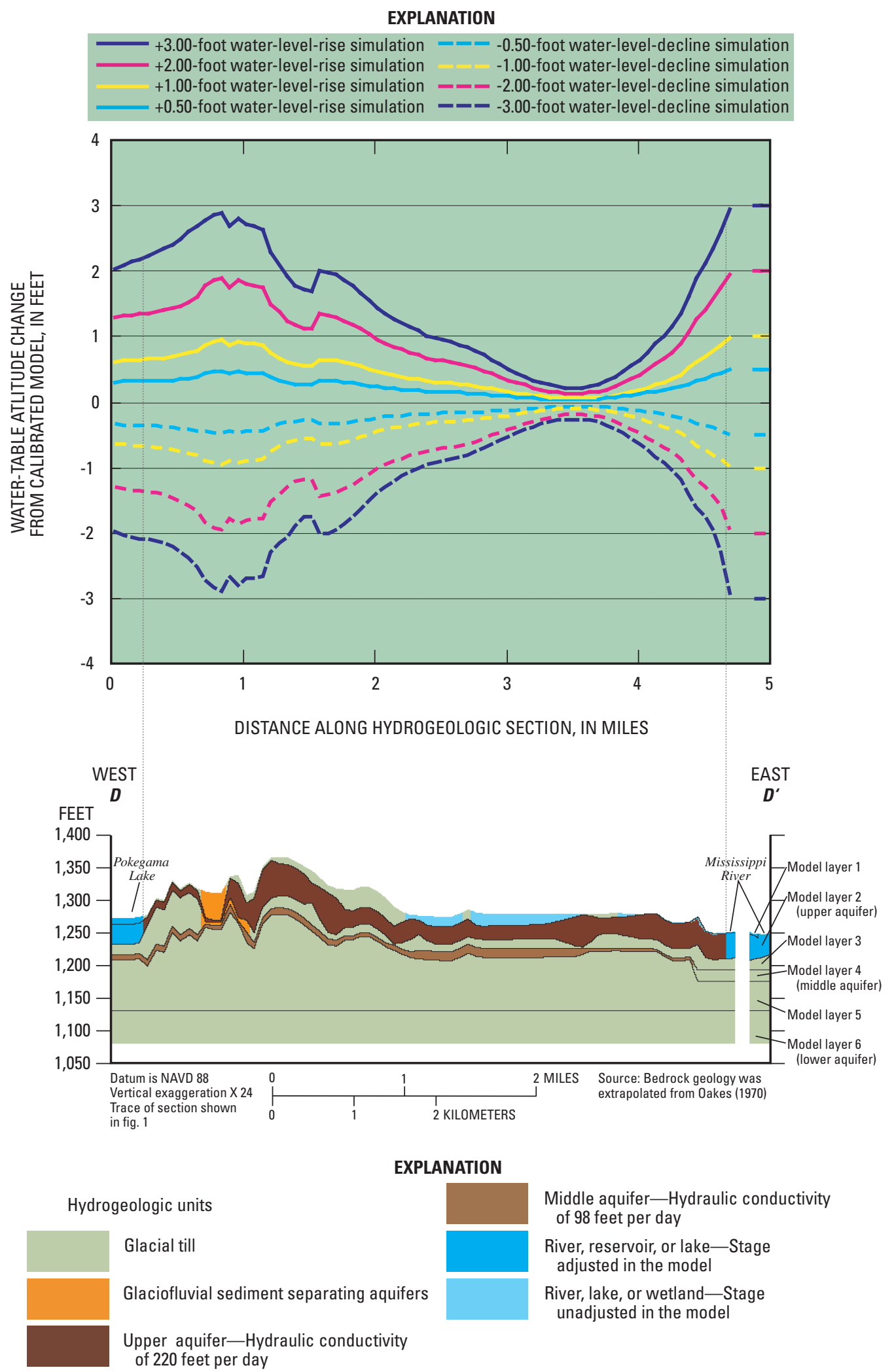

Figure 7. Model-computed changes in water-table altitude for hypothetical water-level changes in the Mississippi River and Pokegama Reservoir compared to steady-state, calibrated values for hydrogeologic section $D-D^{\prime}$, Grand Rapids area, Minnesota. 
simulations, it is evident that the simulated hydraulic conditions do not accurately represent actual conditions in this area.

The large ground-water-level declines in the middle aquifer can be explained by slight differences in depth between the lake bottoms and the top of the middle aquifer, small till thicknesses, and sound hydraulic connection between the aquifers. In the Jay Gould and Little Jay Gould Lake area, the till thicknesses between the upper, middle, and lower aquifers are small to nonexistent, with the middle and lower aquifers being hydraulically connected through highly permeable glaciofluvial sediments (fig. 4). Jay Gould and Little Jay Gould Lakes are connected in the model and intercept the upper aquifer (fig. 4) in the second layer and are adjacent to tills in the third layer of the model. The hydraulic connection between the middle and lower aquifers resulted in large ground-water-level changes in both aquifers. Ground-water-level declines in the lower aquifer were as much as $2.90 \mathrm{ft}$ in the area as a result of the $3.00-\mathrm{ft}$ decline in reservoir and river water levels (fig. 3).

At the Paper Mill Reservoir, the large ground-water-level changes in the middle aquifer (figs. 1 and 2) also can be explained by the depth and extent of the Paper Mill Reservoir and Mississippi River, which intercepts the upper aquifer in the second model layer (fig. 5) and tills in the third layer of the model (fig. 6). The ground-water-level changes in the lower aquifer are smaller in the Paper Mill Reservoir area, less than $1.50 \mathrm{ft}$ with a $3.00-\mathrm{ft}$ decline in surface-water levels (fig. 3). This smaller ground-water-level change is due mainly to the presence of till between the middle and lower aquifers (figs. 5 and 6).

The thickness, extent, and connectivity of the aquifers control the extent of the change in ground-water levels. Where aquifers are discontinuous and thicknesses are small, such as north and south of the Mississippi River upgradient of the Paper Mill Reservoir (fig. 5) and in the Grand Rapids area (fig. 6), the extent of water-table change is small, and therefore, the effect of river and lake water-level change is localized. Although localized, the water-table change associated with the waterlevel decline can be large in these areas. Where aquifers are more continuous, such as north of Jay Gould Lake in hydrogeologic section $A-A^{\prime}$ (fig. 4), north of Pokegama Lake in hydrogeologic section $C-C^{\prime}$ (fig. 6), and east of Pokegama Lake in hydrogeologic section $D-D^{\prime}$ (fig. 7), the extent of water-table change is large, and therefore, the effect of river and lake waterlevel changes is more extensive. The large extent of the watertable changes is due primarily to the relatively large width of the surface-water bodies. Although the extent is large, the watertable change is small where continuous parts of the aquifer are relatively thick, such as north of Pokegama Lake in hydrogeologic section $C-C^{\prime}$ (fig. 6).

\section{Possible Implications of Water-Level Changes in the Mississippi River and Pokegama Reservoir on Adjacent Ground-Water Levels}

The Jay Gould and Little Jay Gould Lake area appears to be the area most sensitive to reservoir and river declines. Ground-water levels declined as much as $1.09 \mathrm{ft}$ in the middle aquifer in response to only a 1.00-ft decline in reservoir and river water levels (figs. 2 and 3) These large ground-waterlevel changes are the result of the small amount of till and the presence of nearby lakes and rivers (figs. 1 and 4). Simulated ground-water-level change is extensive throughout the middle and lower aquifers but generally is less than $1.09 \mathrm{ft}$. Thus, a decrease in reservoir stage of $1.00 \mathrm{ft}$ likely will have minimal effect on local ground-water levels, because these changes are relatively small compared to the water level present in the aquifers and most local wells. Therefore, the lowering of the reservoir and river water levels by $1.00 \mathrm{ft}$ likely will not substantially affect the water levels in wells constructed in the middle and lower aquifers.

Also, the magnitude and extent of the actual ground-waterlevel changes likely will be less than the simulated water-level changes, because the simulated values represent conditions under steady-state flow, where the magnitude and direction of ground-water-flow velocity are constant over time. If a $1.00-\mathrm{ft}$ decline in water level is implemented, the planned water-level change will only occur over a few weeks or months during the year and not over steady-state conditions simulated by the model. Steady-state conditions likely would not be reached throughout the aquifer, and therefore, the magnitude, and particularly the extent of the ground-water-level change likely will be less.

The effect of the 1.00-ft river and reservoir water-level change on ground-water levels under drought conditions likely would be greater than the changes determined by the steadystate model under average recharge conditions due to the lower water levels in the aquifers. However, the difference between these water-level changes would not be substantial. For example, during the drought of 1976-77, water levels in a MDNR observation well in the Grand Rapids area screened in the middle aquifer only declined approximately $2.00 \mathrm{ft}$ from the 30 -year normal water level. The normal standing water level in this well is approximately $114 \mathrm{ft}$, with a range in water levels of approximately $5.00 \mathrm{ft}$ over 40 years of record. The well construction and water-level conditions in the MDNR well are similar to many wells completed in the middle aquifer. Under these conditions, it is unlikely that a 1.09 -ft or more decline in water level at the well would have a substantial effect on the water resource. 


\section{Model Limitations and Accuracy}

Due to a lack of a calibrated, transient, ground-water flow model, a steady-state model was used for this study. The steadystate simulations represent "worse-case" scenarios for the effects of lowering or raising the river and lake water levels. The simulated ground-water levels represent the levels that would result if the river and lake stages permanently declined or rose by the specified amounts. Smaller temporal changes in stage, such as the changes that may occur as part of the USACE's ROPE effort, probably would result in much smaller changes in ground-water levels in the surrounding aquifers.

The calibrated flow model is a simplification of a complex glaciated-terrain, ground-water flow system. The accuracy of the simulations is limited to the accuracy, amount, and distribution of the data used to describe the hydrologic variables of the flow system and the accuracy of the assumption of steady state. These variables include the hydrologic properties of the aquifers and confining units, areal recharge rates, and hydrologic boundary conditions. Variables determined for the model during calibration may not be unique. Different combinations of variables for the model could produce similar results. The model grid was designed to simulate hydrologic conditions at the scale of the study area. Therefore, the model may not accurately represent small-scale flow conditions where local variations from more regional patterns may exist.

The calibrated model is a tool for water-resources management that is based on the assumption that future hydrologic conditions will be similar to historical or assumed steady-state conditions. Furthermore, it was assumed that variations in annual recharge and discharge for the hypothetical simulations were similar to the hydrologic conditions of the calibrated model. Accuracy of the hypothetical simulation becomes more uncertain if the variation in annual recharge or discharge exceeds the range used in the calibrated model. Because the numerical model was calibrated under the assumption of steady-state flow conditions, the model most accurately reflects the effects of long-term, annual, or multiple-year stresses.

\section{Summary}

The U.S. Geological Survey, in cooperation with the U.S. Army Corps of Engineers, used an existing, three-dimensional, numerical ground-water flow model (referred to as the calibrated model) to assess the effects of water-level changes in the Mississippi River and the Pokegama Reservoir on ground-water levels in adjacent glaciofluvial aquifers in the Grand Rapids area of north-central Minnesota. Pokegama Reservoir consists of Pokegama Lake, Little Jay Gould Lake, Jay Gould Lake, Cut-off Lake, and Blackwater Lake. Water levels in the Pokegama Reservoir are regulated at Pokegama Dam on the Mississippi River west of Grand Rapids. A steady-state model was used for this study, and the simulations represent "worse-case" scenarios for the effects of lowering or raising the river and lake water levels. The simulated ground-water levels represent levels that would result if the river and lake stages permanently declined or rose by the specified amounts. Eight simulations were executed and analyzed on the basis of varying Mississippi River and Pokegama Reservoir water levels from values used in the calibrated model. In the simulations, water levels for the Mississippi River, riverine wetlands of the Mississippi River, and lakes of the Pokegama Reservoir were raised and lowered uniformly by $0.50,1.00,2.00$, and $3.00 \mathrm{ft}$ from the calibrated model levels. Ground-water-level altitudes calculated in the simulations were compared to water-level altitudes in the calibrated model to determine the amount of water-level change from those of the calibrated model.

The extent of aquifer water-level changes resulting from the raising or lowering of Mississippi River and Pokegama Reservoir water levels varied because of the complex hydrogeology of the study area. The maximum ground-water-level decline in the middle aquifer was $1.09 \mathrm{ft}$ for a $1.00-\mathrm{ft}$ decline in reservoir/river water levels, which occurred near the Jay Gould and Little Jay Gould Lake area. The maximum ground-water-level decline in the lower aquifer was $1.00 \mathrm{ft}$ for a $1.00-\mathrm{ft}$ decline in reservoir/river water levels, which occurred near Cut-off Lake, Blackwater Lake, and in the Jay Gould and Little Jay Gould Lake area. The amount and extent of ground-water-level changes in the middle and lower aquifers can be explained by the thickness, extent, and connectivity of the aquifers. Surfacewater/ground-water interactions near wetlands and lakes with water levels unchanged from the calibrated model resulted in small water-table altitude differences among the simulations. Results of the ground-water modeling indicate that lowering of the reservoir and river water levels by $1.00 \mathrm{ft}$ likely will not substantially affect water levels in the middle and lower aquifers.

\section{Acknowledgments}

The author thanks the U.S. Army Corps of Engineer, in particular Mr. Edward McNally and Mr. Kenton Spading, for providing assistance needed to complete this study, Geoffrey Delin and Brian Clark, U.S. Geological Survey, for technical reviews, Robert Borgstede for illustrations preparation, and Lanna Combs for editorial review. 


\section{References}

Harbaugh, A.W., and McDonald, M.G., 1996, User's documentation for MODFLOW-96, an update to the U.S. Geological Survey modular finite-difference ground-water flow model: U.S. Geological Survey Open-File Report 96-485, 63 p.

Jones, P.M., 2004, Simulation of ground-water flow in glaciofluvial aquifers in the Grand Rapids area, Minnesota: U.S. Geological Survey Scientific Investigation Report 2004-5159, 23 p.

Minnesota Department of Natural Resources, 2002, Lake finder, 1996: Information available on the World Wide Web, accessed March 25, 2002, at URL http://www.dnr.state.mn.us/lakefind/index.html

Minnesota State Climatologist, 2001, Normal precipitation and temperature data: Information available on the World Wide Web, accessed July 11, 2001, at URL http://climate.umn.edu/doc/historical/normals.htm

Morey, G.B., 1972, Mesabi Range, in Sims, P.K., and Morey, G.B., eds., Geology of Minnesota-a centennial volume: Minnesota Geological Survey, p. 204-217.

Oakes, E.L., 1970, Geology and ground-water resources of the Grand Rapids area, north-central Minnesota: U.S. Geological Survey Hydrologic Investigations Atlas HA-322, scale 1:48,000.
Payne, G.A., 1995, Ground-water base flow to the upper Mississippi River upstream of the Minneapolis-St. Paul area, Minnesota, during July 1988: U.S. Geological Survey OpenFile Report 94-478, 28 p.

U.S. Army Corps of Engineers, 2003a, Reservoir Operating Plan Evaluation (ROPE) study for Mississippi headwaters: Information available on the World Wide Web, accessed March 19, 2003, at URL http://www.mvp.usace.army.mil/fl_damage_reduct/ default.asp?pageid $=143$

U.S. Army Corps of Engineers, 2003b, Upper Mississippi River water level management study: Information available on the World Wide Web, accessed March 19, 2003, at URL http://www.mvp.usace.army.mil/environment/ default.asp?pageid $=122$

U.S. Census Bureau, 2002, Population data: Information available on the World Wide Web, accessed February 6, 2002, at URL http://factfinder.census.gov/servlet/BasicFactsServlet

U.S. Department of Defense, 1998, Groundwater modeling system, user's manual: Provo, Utah, Brigham Young University. p. 1-5.

U.S. Fish \& Wildlife Service, 1994, National wetlands inventory digital data, October 1991 to 1994: Information available on the World Wide Web, accessed February 11, 2002, at URL http://www.nwi.fws.gov 